\title{
Left behind? Over-time change in the social mobility of children from unskilled working-class backgrounds in Germany
}

\begin{abstract}
Research on intergenerational social mobility tends to focus on examining the level of overall social fluidity in society. However, from a social justice perspective it can be argued that the type of social fluidity that matters most is upward mobility from the lowest rung of the social ladder. This article examines the labour market chances of children from parents in unskilled working-class positions, relative to children from skilled working-class and higher social class backgrounds, and how they have changed across four birth cohorts in post-WWII Germany. We find that individuals from unskilled working-class backgrounds have substantially lower labour market chances than individuals from skilled working-class or higher social class backgrounds. Moreover, we find that the gap in labour market chances between individuals from unskilled working-class backgrounds and individuals from more advantaged backgrounds has not narrowed, but if anything has widened across the four birth cohorts we examine. Our results suggest that an important factor underlying this sustained labour market inequality is a persistently bigh level of educational inequality between these groups.
\end{abstract}

Key words: Intergenerational social mobility, Social inequality, Educational inequality, Equality of opportunity, Intergenerational transmission of inequality, Disadvantaged youth, Germany, Social justice

Word count: 7827 
Author: Dr Bastian A Betthäuser

Postdoctoral Prize Research Fellow

Nuffield College, University of Oxford

1 New Road, Oxford OX1 1NF, United Kingdom

Office: $+44(0) 1865278693$

Mobile: +44 (0) 7596485766

bastian.betthaeuser@nuffield.ox.ac.uk

Biographical note: Bastian A Betthäuser is a Postdoctoral Prize Research Fellow at Nuffield College, University of Oxford. His research examines the micro-level mechanisms underlying the intergenerational transmission of inequality and the extent to which they are moderated by macro-level institutions, particularly education and labour market policy.

Acknowledgements: The author would like to express his gratitude to Erzsébet Bukodi, John H. Goldthorpe, Anette Fasang, Brian Nolan, Johan Bo Davidsson, Mollie Bourne, Alexi Gugushvili, Marieke Oudelaar, the participants of the Social Inequality Research Group at the University of Oxford, as well as the editors and three anonymous reviewers at Acta Sociologica for their invaluable comments on earlier drafts of this article. 


\section{Introduction}

Existing research on intergenerational social mobility tends to focus on examining the level of overall social fluidity in society. Consequently, we still know relatively little about the social mobility of specific groups and how it has changed over time. This article focuses on the over-time change in the labour market chances of children from unskilled working-class backgrounds. Having been born into a family at the very bottom of the social class spectrum, these individuals can be seen as having drawn the worst ticket in the lottery of birth' (Rawls, 1971). It follows that, from a normative, social justice perspective, whether or not they can improve their social position by being upwardly mobile is of greater concern than is the social mobility of individuals coming from more advantaged social backgrounds.

Past research on over-time change in social fluidity in Germany finds a trend of increasing social fluidity across cohorts born in the early and mid $20^{\text {th }}$ century, i.e. a weakening of the association between individuals' social class position and that of their parents, net of changes in the social class structure (Müller and Pollak, 2004; Breen and Luijk, 2007; Breen, 2010). However, there is some evidence that this trend of increasing social fluidity has levelled out or even reversed for people born in the second half of the $20^{\text {th }}$ century (Mayer and Aisenbrey, 2007). In light of these broader trends, the first aim of this article is to examine the over-time change in the labour market chances of individuals from unskilled working-class backgrounds, relative to individuals from higher social class backgrounds, across four cohorts born in 1940-49, 1950-59, 1960-69 and 1970-79. ${ }^{1}$ As discussed in further detail in the next section of the paper, comparing individuals across these four birth cohorts is of particular interest as they grew up and entered the labour market under highly distinct economic circumstances. Given that the institutional context and the dynamics of intergenerational transmission of inequality have been shown to differ substantially between former East and West Germany (see, e.g., Betthäuser, 2019; Pollak and Müller, 2004; Mayer and Solga, 1994), we focus our analysis on individuals born in West Germany.

The second aim of this article is to examine the role of educational inequality in accounting for the difference in the labour market chances of children from unskilled working-class backgrounds and their more advantaged peers, and how it has changed over time. As illustrated by the well-known 'OED triangle', the total effect of individuals' social origin on their social destination can be decomposed into two parts: one that is mediated by children's educational attainment and one not mediated by education-the so-called 'direct' effect of social origin (see, e.g., Goldthorpe, 2007:159; Bernardi and Ballarino, 2016, Gugushvili et al., 2017). Past research suggests that in Germany a substantial proportion of 
the total effect of parents' social class background on their offspring's labour market position is mediated via individuals' educational attainment (Müller and Pollak, 2004:107). However, it has been argued that this mediating role of education is weaker for people from unskilled working-class backgrounds (Ishida et al., 1995:177). We use a new decomposition method developed by Karlson, Holm and Breen (2012) and a series of logistic regression models to estimate the proportion of the effect of social origin on social destination that is mediated by education and the extent to which the associations between the different components of the OED triangle have changed over time.

This paper uses social class as an indicator of individuals' position in society, as it is known to be a key determinant of individuals' economic security in industrial and postindustrial economies (Breen and Rottman, 1995; Marshall, 1997; Goldthorpe and Marshall, 1992; Wright, 2008; Crompton, 2008; Scott, 1996). As such, parents' social class position is a key determinant of the economic resources available to their children during their educational trajectory and transition into the labour market (see, e.g., Shavit and Blossfeld, 1993; Bernardi and Ballarino, 2016; Pfeffer and Hällsten, 2012). ${ }^{2}$ Children of parents in unskilled working-class positions are considered to be at a particular disadvantage, as in Germany the working and living conditions between the unskilled and skilled working class differ substantially. In the German 'dual labour market', people in skilled working-class positions enjoy a relatively high level of economic security due to labour market institutions such as collective wage bargaining, employment protection legislation and high unemployment insurance benefits, while individuals in the unskilled working class generally receive substantially less institutional support (see Betthäuser, 2017; Emmenegger et al, 2012; Lindbeck and Snower, 1988; Leibfried and Tennstedt, 1985).

\section{Why expect over-time change in social mobility?}

Changes in educational inequality and economic inequality in society are generally thought to be two important macro-level factors shaping the level of intergenerational social mobility in society. This section discusses whether and how changes in these two domains may be expected to have affected the labour market chances of individuals from unskilled workingclass backgrounds, relative to individuals from higher social class backgrounds.

Attempts of explaining the trend of increasing overall social fluidity in Germany have highlighted the role of a decline in educational inequality between individuals from different social class origins and an increase in the share of people with high levels of educational attainment, the latter being generally referred to as 'educational expansion'. More specifically, past research attests a decline in educational inequality in Germany over the course of the 
$20^{\text {th }}$ century (see, e.g., Müller and Pollak, 2004), which_-given the known role of education in mediating the association between social origin and destination-is thought to have led to an increase in social fluidity (Breen, 2010). Moreover, based on the observation that the origin-destination association tends to be weaker for people with higher levels of educational attainment in Germany and other western societies (Breen, 2010; Breen and Jonsson, 2007, Hout, 1988), it has been argued that the educational expansion in Germany also contributed to an increase in overall social fluidity (Breen, 2010; Breen et al., 2009, 2010).

If the trends of educational equalization and expansion were to have had an effect on the inequality in labour market chances between individuals from unskilled working-class backgrounds and individuals from higher social class backgrounds, we would expect to find a gradual increase in the relative labour market chances of individuals from unskilled working-class backgrounds across the four cohorts we consider. However, while these trends may account for the observed increase in overall social fluidity during the $20^{\text {th }}$ century, it is not clear that they also led to an increase in the mobility chances of individuals from unskilled working-class backgrounds. With the notable exception of an extension of compulsory schooling in all German states (Bundesländer) during the two decades following World War II (see Betthäuser, 2018; Müller and Haun, 1994), there have been few reforms of the German education system which can be expected to have substantially reduced the educational inequality between this group and people from more advantaged backgrounds (see, Bukodi et al., 2017, Neugebauer et al., 2013; Schneider, 2006). Moreover, given the generally low level of educational attainment of people from disadvantaged backgrounds (Shavit and Blossfeld, 1993), it is questionable whether the trend of educational expansion in Germany has increased the educational attainment of this group to an extent that would have given rise to a weakening of the effect of their parental class background on their labour market chances. It thus remains an empirical question to what degree there has been a decline in the educational inequality at the bottom of the social class structure and whether educational expansion has led to an increase in the relative labour market chances of people from unskilled working-class backgrounds.

Aside from the dynamics of educational equalization and expansion, the level of economic inequality in society is generally thought to be an important macro-level factor affecting the level of social fluidity in society (Corak, 2013; Andrews and Leigh, 2009). It has been argued that the level of economic resources that parents can use to support their children's education and transition into the labour market is a key determinant of the latter's educational attainment and labour market position (Erikson and Goldthorpe, 1992). Consequently, a high level of inequality in economic resources in the parental generation is seen to lead to a high level of inequality in the educational and labour market chances of 
children from different social backgrounds (Corak, 2013; Andrews and Leigh, 2009, but see Bukodi et al., 2017), and vice versa. Changes in the level of parental economic resources are likely to have a particularly strong effect at the bottom of the social class structure, where parents have to make hard choices about the amount of economic resources that they can devote to supporting their children's early development, education and labour market entry.

The level of economic security of people in unskilled working-class positions relative to people in higher social class positions has varied considerably across the four birth cohorts we examine. Following the post-war economic depression, the rapid economic growth and the expansion of the welfare state during the Wirtschaftswunder of the 1950s and 60s led to full employment, rising living conditions and social security, which is likely to have benefitted particularly people at the bottom of the income distribution (see Kaelble, 2007: 187-8; Atkinson, 2008:230). By contrast, the relative economic security of this group can be expected to have declined during the period following the 1970s Oil Crisis, which saw a substantial increase in unemployment, economic inequality, relative poverty and a retrenchment of unemployment benefits for people with low unemployment insurance contribution records (Leibfried et al., 1995; BMAS, 2001; OECD, 2011; Ostheim and Schmidt, 2007; Eichhorst and Marx, 2011; Emmenegger et al, 2012).

If these historic developments were to have had a bearing on the relative labour market chances of people from unskilled working-class backgrounds, we would expect the post-war depression to have had a negative effect on the relative labour market chances of this group in the 1940s cohort, while individuals from unskilled working-class backgrounds in the 1950s cohort and to some extent in the 1960s cohort may be expected to have benefitted from the shared prosperity of the Wirtschaftswunder (see Table 1). The relative labour market chances of people from unskilled working-class backgrounds in the 1970s cohort may be expected to have been negatively affected by the Oil Crisis and the welfare state retrenchment that began in the early 1970s. It should be noted that we do not aim to establish the causal effects of these macro-level trends, but rather use them to guide our empirical analysis and to interpret our findings in relation to the historical context of postWWII Germany.

— Table 1 about here -

\section{Data and variables}

We use the German Socio-Economic Panel Study (SOEP) as the primary dataset for our analyses (see Wagner et al., 2007). In order to avoid any potential bias due to survey 
specificities, we verify the robustness of our results by running all our models on a secondary dataset, the German General Social Survey (ALLBUS/GGSS) (see Wasmer et al., 2014). Both the SOEP and the ALLBUS provide detailed information on the social class position and education of respondents and their parents, and the two datasets have been widely used for the analysis of intergenerational social mobility in Germany (see, e.g., Pollak, 2000; Pollak and Müller, 2004; Hertel, 2017). All results reported in the main body of the text are based on the SOEP data. The results from our replication analyses based on the ALLBUS data are given in the Appendix. While most previous research on educational and labour market inequalities in Germany uses the 'complete case analysis' approach and thus relies on the assumption that missingness in the data is completely at random (White et al., 2010), we impute missing data points using multiple imputation by chained equations and thereby limit the risk of potential bias related to systematic item missingness in our data.

Individuals' and parents' social class position is operationalised using the European Socio-Economic Classification (ESeC), which was developed by Rose and Harrison (2010) and has been validated for Germany and other European countries (Wirth et al., 2010). The ESeC class schema is particularly well suited for our analysis as it allows for a clear differentiation of the unskilled working class (ESeC 9) from the skilled working class (ESeC 7 and 8) and higher classes. ${ }^{3}$ Given that individuals' social class position tends to stabilise after age 34 (see, e.g., Bukodi and Goldthorpe, 2011), we reduce our sample to individuals aged between 34 and 64 and control for respondents' age in all our analyses.

Our analysis focuses on two binary dependent variables. The first indicates whether individuals have attained a labour market position in the skilled working class or above. The second indicates whether individuals have attained a position in the intermediate class or the salariat. As discussed above, obtaining a position in the skilled working class in Germany provides people with substantially more secure working and living conditions, compared to being in the unskilled working class. In turn, gaining a position in the intermediate class or the salariat can be expected to constitute a further significant increase in the level of economic security, mainly due to the higher earnings of individuals in these class positions. Using these two 'labour market cut-offs' as dependent variables allows us to examine both the short- and long-range mobility chances of individuals from unskilled working-class backgrounds.

Mirroring our dependent variable, parents' class position is measured using a threecategory version of the $\mathrm{ESeC}$ schema, differentiating between (1) the unskilled working class, (2) the skilled working class, and (3) the intermediate class and salariat. We derive parents' class position from fathers' and mothers' class positions using the dominance approach, which allocates parents to a social class position according to the higher social class position 
of the two spouses (see Erikson, 1984). The parental class position is measured at age fifteen of the cohort members, i.e. when they were at the end of their lower-secondary education.

Cohort members' educational attainment is measured using a four-category variable distinguishing between individuals whose highest educational qualification is (1) a midsecondary qualification (Realschulabschluss), lower secondary qualification (Hauptschulabschluss) or less, (2) an upper secondary qualification (Abitur or Berufsausbildung), (3) a post-secondary qualification (Meister or equivalent), or (4) a tertiary qualification (Universitätsabschluss or Fachhochschulabschluss). We measure individuals' educational attainment at the age at which we observe their social class position. We control for individuals' gender in all our analyses and have conducted separate robustness checks which lead us to the same conclusions for both women and men.

Table 2 shows the distribution of our focal variables across the four birth cohorts we examine. In the parental generation, there has been an expansion of the intermediate class and salariat across the four cohorts, which is mirrored by a contraction of the skilled working class, while the share of people in the unskilled working class has remained relatively stable. By contrast, the social class structure remained stable across the four cohorts in the respondents' generation. This is in line with previous findings on the development of the German social class structure (see, e.g., Müller and Pollak, 2015). As expected, we observe a trend of educational expansion across our four birth cohorts.

- Table 2 about here -

\section{Results 1: Over-time change in social mobility}

As noted above, our first aim is to provide a descriptive account of labour market inequality between people from unskilled working-class backgrounds and people from more advantaged backgrounds, and how this has changed over time. To this end, we apply two binary logit models for each of our two dependent variables, i.e. attaining a position in the skilled working class or above (Cut-off 1 ) and attaining a position in the intermediate class or above (Cut-off 2). We include our measure of parental class as the focal explanatory variable, as well as an interaction between parental class and birth cohort.

— Figure 1 about here —

Based on these models, Figure 1 shows the predicted probabilities of individuals from different social class backgrounds to attain a position above the two labour market cut-offs. 
All odds ratios of the models are shown in Table A1 in the Appendix. As indicated by the distance between the lines in Figure 1, we find a substantial difference in the labour market chances of people from unskilled working-class backgrounds, people from skilled workingclass backgrounds and people from intermediate class and salariat backgrounds. The probability of people from unskilled working-class backgrounds born in the 1940s to attain a position in the skilled working class or above, i.e. to cross Cut-off 1 , was about 75 percent, while it was about 85 percent for people from skilled working-class positions and about 95 percent for people from intermediate class or salariat backgrounds. Similarly, the probability of people from unskilled working-class backgrounds to attain a position in the intermediate class or above, i.e. to cross Cut-off 2, was about 48 percent, while it was about 60 percent for people from skilled working-class backgrounds and about 82 percent for people from intermediate class or salariat backgrounds. In short, the difference in the labour market chances of individuals from unskilled working-class backgrounds and people from more advantaged backgrounds was about ten percentage points or higher in the 1940s birth cohort.

With regards to over-time change across the first two birth cohorts-i.e. the 1940s and the 1950s cohorts-Figure 1 suggests that there may have been an increase in the labour market chances of individuals from unskilled working-class backgrounds, relative to individuals from skilled working-class and higher social class backgrounds. However, this over-time change is not statistically significant (see Table A1, M2). With regards to the second labour market cut-off, we find a statistically significant general increase in the absolute likelihood of all individuals to obtain a position in the intermediate class or above between the 1940s and 1950s cohorts (see Figure 1 and Table A1, M3). This reflects an increase in the proportion of jobs in higher social classes at the time of the German Wirtschaftswunder. Yet, this shift in the social class structure appears to have benefitted people from unskilled working-class backgrounds and people from higher social class backgrounds to similar extents, thus leaving the relative labour market chances between them unchanged. In sum, we do not find evidence for the expectation that the expansion of the welfare state and the rise in economic prosperity during the Wirtschaftswunder increased the relative labour market chances of people from unskilled working-class backgrounds.

With respect to over-time change across the last three birth cohorts-i.e. the 1950s, 1960s and 1970s cohorts - we also find no evidence for a decline in the labour market inequality between people from unskilled working-class backgrounds and people from higher social class backgrounds. Instead, Figure 1 suggests that, if anything, there may have been a modest widening of the gap in labour market chances between these groups across the three birth cohorts. This trend is statistically significant at the second labour market cut- 
off for the contrast between individuals from unskilled and skilled working-class backgrounds (Table A1, M2 and M4). ${ }^{4}$ This suggests that the levelling-off of the trend of increasing social mobility for individuals born in the second half of the $20^{\text {th }}$ century that has been demonstrated in the existing literature (see Mayer and Aisenbrey, 2007) may have been driven by a decline in the mobility chances of individuals from unskilled working class backgrounds.

\section{Results 2: Education as a channel for the intergenerational transmission of disadvantage}

Our second research question focuses on the role of educational inequality in accounting for the persistent inequality in the labour market chances of people from unskilled workingclass backgrounds and people from more advantaged backgrounds. More specifically, we seek to assess to what extent educational attainment mediates the effect of growing up in an unskilled working-class family on individuals' own social class position and how this mediating role has changed over-time

As noted above, we use the decomposition method developed by Karlson, Holm and Breen (2012) to estimate the percentage of the total effect of parental class on individuals' labour market chances that is mediated via individuals' educational attainment. ${ }^{5}$ Figure 2 shows this mediation percentage for each of our four birth cohorts, separately for the two labour market cut-offs. By way of example, the first dot in Figure 2 indicates that for people born in the 1940s about half of the effect of growing up in a skilled working-class family as opposed to growing up in an unskilled working-class family (the reference category) is mediated by individuals' level of educational attainment. Importantly, this proportion appears to be highly stable across the four birth cohorts and across both labour market cutoffs. ${ }^{6}$ In other words, in all four birth cohorts about half of the labour market disadvantage of individuals from unskilled working-class backgrounds can be explained by the fact that they leave the educational system with lower educational qualifications than is the case for individuals from higher social class backgrounds. ${ }^{7}$ Importantly, this finding contradicts past research which claims that education does not play a prominent role in explaining the labour market disadvantage experienced by children from unskilled working-class families (cf. Ishida et al., 1995:177). ${ }^{8}$

— Figure 2 about here —

While Figure 2 suggests stability in the role of education in channelling the intergenerational transmission of disadvantage in Germany, this stability may mask more subtle changes in 
the associations within the abovementioned 'OED triangle', i.e. (1) the association between individuals' parental class background and their educational attainment, (2) the association between individuals' educational attainment and their social class position, and (3) the 'direct' association between individuals' parental class background and their social class position, not mediated by education. Given the expansion of the 'knowledge economy' that began in Germany in the early 1970s (Wren, 2013; Seeleib-Kaiser et al., 2011), one could, for example, expect a strengthening of the association between individuals' educational attainment and their social class position (cf. Bell, 1976), which may have compensated a possible weakening in the association between parental class and educational attainment. Such countervailing over-time changes may not be reflected in changes in the proportion of the parental class effect that is mediated by education, which we estimated above.

— Table 3 about here -

In order to examine whether there have been any over-time changes in the associations that comprise the OED triangle, we first focus on the association between individuals' parental class background and their educational attainment. To this end, we run two ordered logit models with the four-category educational attainment variable described above as the dependent variable, first including parental class as the main explanatory variable (Table 3, M1) and then adding an interaction between parental class and birth cohort membership (Table 3, M2). ${ }^{9}$ The interaction terms shown in M2 of Table 3 suggest a persistent gap in the educational attainment between individuals from unskilled working-class backgrounds and people from higher social class backgrounds across the four birth cohorts we examine. This finding contrasts with the finding of a decline of educational inequality in Germany over the course of the $20^{\text {th }}$ century (see, e.g., Breen 2010), and suggests that this general trend does not appear to have benefitted children from unskilled working-class backgrounds in the four cohorts we examine.

— Table 4 about here -

The next step of our analysis examines, first, the association between individuals' educational attainment and their labour market position, and second the direct effect of peoples' social class background on their labour market position, net of educational attainment. We apply two sets of binary logit models for each of the two labour market cutoffs. In the first set of models we include individuals' educational attainment and parental class background as the focal explanatory variables (Table 4, M1 and M3). In the second set 
of models we then add an interaction between educational attainment and birth cohort membership, as well as an interaction between parental class background and birth cohort membership (Table 4, M2 and M4).

As expected, the main effect of our measure of educational attainment shown in M1 and M3 indicates that individuals' level of education exerts a strong influence on their chances to attain a position above either of the two labour market cut-offs. However, the interaction terms between educational attainment and birth cohort membership shown in M2 and M4 suggests that there has been no systematic change in this association across the four birth cohorts we examine. This finding contradicts the expectation that the "knowledge economy' has led to a strengthening of this association across the birth cohorts we examine (cf. Bell, 1976).

With regards to the direct effect of individuals' social class background on their labour market position, net of educational attainment, the main effect of our measure of parental class shown in M1 and M3 confirms our finding from the decomposition analysis that parents' class position affects individuals labour market position not only via their educational attainment, but also 'directly', or rather through other mechanisms. ${ }^{10}$ However, the interaction between parental class and birth cohort in M2 and M4 suggests little evidence for any systematic change in this direct effect of peoples' parental class background on their labour market chances across the four birth cohorts we consider. ${ }^{11}$

\section{Conclusion}

While past research on intergenerational social mobility has focussed on measuring the level of overall social fluidity in society, this paper examines the social mobility chances of the specific group of individuals born into unskilled working-class families. From a normative, social justice standpoint, we consider the mobility chances of individuals in this group to be of particular importance, given their disadvantaged position at birth. The overarching aim of this paper has been to demonstrate the importance of considering changes in the social mobility of specific group of individuals-particularly those born into disadvantaged conditions - as these may diverge from more general changes in social fluidity. To this end, we have sought, first, to provide a descriptive account of the inequality in the labour market chances between individuals from unskilled working-class backgrounds and people from more advantaged social class backgrounds, and of how this inequality has changed over time in Germany. Second, we examined the role of educational inequality in accounting for the 
difference in the labour market chances of children from unskilled working-class backgrounds and their more advantaged peers, as well as the over-time change therein.

Our first main finding is that there appears to be a substantial gap between the labour market chances of individuals from unskilled and skilled working-class backgrounds. More specifically, we find a difference of about ten percentage points in the chances of the individuals in these groups to attain a position above the two labour market cut-offs we examine. This difference is as large as the difference in the labour market chances between individuals from skilled working-class backgrounds and individuals from intermediate-class origins. Our finding demonstrates that the stratification within the working class plays an important role in the intergenerational transmission of inequality in Germany. This is likely to be a result of the substantial difference in the working and living conditions between the unskilled and skilled working class in Germany. In the German 'dual labour market', individuals in skilled working-class positions enjoy a relatively high level of economic security due to labour market institutions such as collective wage bargaining, employment protection legislation and high unemployment insurance benefits, while individuals in the unskilled working class generally receive substantially less institutional support (see Betthäuser, 2017; Leibfried and Tennstedt, 1985).

Second, we find that the gap in the labour market chances between people from unskilled working-class backgrounds and people from higher social class backgrounds has not narrowed significantly across the first three birth cohorts we examine. This finding of a persistent inequality in the labour market chances between these groups contrasts with the pattern of increasing overall social fluidity in Germany that has been shown in past research (Müller and Pollak, 2004; Breen and Luijk, 2007; Breen, 2010). While there appears to have been an increase in the overall level of absolute upward mobility between the 1940s and 1950s cohorts at the time of the German Wirtschaftswunder, this trend seems to have benefitted individuals from unskilled working-class backgrounds and individuals from higher social class backgrounds to similar extents, thus leaving relative social mobility rates of these groups unchanged.

However, we find a decline in the labour market chances of individuals from unskilled working-class backgrounds, relative to individuals from higher social class backgrounds, between the 1960s birth cohort and the 1970s birth cohort. This trend may be a result of the 1970s Oil Crisis and the concomitant welfare state retrenchment, which is likely to have had a particularly negative effect on the economic security of families at the bottom of the social class hierarchy. Given the importance of economic resources in the parental generation, the differential effect of the 1970s Oil Crisis and the concomitant welfare state retrenchment is likely to have contributed to the observed widening of the gap 
in the labour market chances of individuals from unskilled working-class backgrounds and individuals from more advantaged backgrounds. This is in line with the existing evidence on the rigidifying effects on economic crisis on social mobility (Jackson and Evans, 2017). The decline in the relative labour market chances of individuals from unskilled working-class backgrounds between the 1960s birth cohort and the 1970s birth cohort that we observe may account for the levelling-off of the trend of increasing overall social mobility that has been demonstrated in the existing literature (see Mayer and Aisenbrey, 2007).

Our third main finding is that about half of the gap in the labour market chances between people from unskilled working-class backgrounds and people from more advantaged backgrounds can be attributed to the fact that children from unskilled workingclass families tend to leave school with lower educational qualifications than is the case for children from more advantaged backgrounds. This considerable role of education in channelling the effect of individuals' class background on their labour market chances appears to be stable across the four birth cohorts we examine. The finding of over-time stability in the mediating role of education is confirmed by the results of our step-wise analysis of the associations between individuals' social origin, their educational attainment and their social destination, as conceptualised through the OED triangle. In short, in all four birth cohorts about half of the labour market disadvantage of individuals from unskilled working-class backgrounds can be explained by the fact that they leave the educational system with lower educational qualifications than is the case for individuals from higher social class backgrounds. Importantly, this finding contradicts past research which claims that education does not play a prominent role in explaining the labour market disadvantage experienced by children from unskilled working-class families (cf. Ishida et al., 1995:177).

When interpreting over-time change in the disadvantage of people from unskilled working-class backgrounds in terms of their educational and labour market prospects, it is important to consider possible over-time changes in the composition of this group with regards to different individual-level characteristics, such as cognitive and socio-emotional attributes, family structure, number of siblings, ethnicity or the educational and sociocultural resources these individuals can rely on during their education and labour market entry. Such compositional changes may counteract or even cancel out any potential effects of the institutional and economic circumstances under which the different birth cohorts received their education and entered the labour market. While a comprehensive investigation of possible compositional changes with regards to all relevant individual-level characteristics lies beyond the scope of this article, we investigate whether there has been any over-time change in the cultural and educational resources that children in this group can draw on, relative to people from more advantaged backgrounds, as indicated by their parents' social 
status and educational attainment (Bukodi and Goldthorpe, 2013). We find that there has been no substantial change in this regard across the four cohorts we consider (see Table A5 in the Appendix), and the fact that the proportion of individuals with parents in unskilled working-class positions did not change substantially across the four birth cohorts we examine renders substantial changes in the composition of this group unlikely (see Table 2).

In sum, this article has shown the importance of examining the social mobility patterns of specific societal groups-particularly of those that face the most disadvantaged conditions when growing up-in addition to changes in overall social fluidity. Using this approach, we found that — contrasting with past findings of an increase in overall social fluidity in Germany-individuals who grow up in unskilled working-class backgrounds in Germany have not experienced any increase in mobility, compared to individuals from more advantaged backgrounds, across the four birth cohorts we examine. To the contrary, we find evidence that the relative social mobility of this group has decreased for people born in the 1970s. An important task for future research will be to examine the extent to which this trend continues for younger birth cohorts, once these have reached the stage of occupational maturity.

\footnotetext{
${ }^{1}$ Given that individuals' educational experiences are known to be an important determinant of their labour market chances in Germany (Müller and Gangl, 2003), and since educational experiences vary primarily by birth cohort, we adopt a cohort perspective rather than a period perspective on over-time change (see, Breen and Jonsson, 2007; Breen and Luijkx, 2007).

2 For a discussion of the micro-level mechanisms through which individuals' parental class background is thought to affect their educational and labour market chances, see Goldthorpe (2007); Breen and Jonsson (2005), Jackson (2013) and Bernardi and Ballarino (2016).

${ }^{3}$ It should be noted that here the terms 'skilled' and 'unskilled' refer to the level of skill typically used in a given occupational group, not the level of educational attainment of the observed individuals in either occupational group (Rose and Harrison, 2010).

${ }^{4}$ Replicating our models using the ALLBUS data leads us to the same conclusions (see Table A2 and Figure A1 in the Appendix). However, it should be noted that the ALLBUS data show the increase in the inequality between individuals from unskilled and skilled working-class backgrounds to be statistically significant for the first labour market cut-off, but not for the second labour market cut-off. We also find that same empirical pattern when we use the UNIDIFF approach to modelling over-time changes in relative social mobility. When modelling over-time change across the entire social class spectrum, we find stagnation across the first three birth cohorts, but a statistically significant decline in relative mobility between the 1960 and 1970 cohort (see Table A6). This decline in relative mobility is even more pronounced when we model changes in mobility between individuals from unskilled working class backgrounds and individuals from higher social class backgrounds (see Table A7), suggesting that the decline in the relative mobility chances of individuals from unskilled working class backgrounds may drive the general pattern of relative social mobility.

5 This method extends the decomposition properties of linear models to nonlinear probability models. It is derived from a linear latent variable model assumed to underlie the logit or probit model. For an in-depth
} 
discussion of this method see Karlson et al. (2012). The method developed by Karlson et al. (2012) does not provide confidence intervals for the estimated mediation percentages.

${ }^{6}$ This finding also emerges from our separate analyses using the ALLBUS data (see Figure A2 in the Appendix). Perhaps surprisingly, given the known importance of educational qualifications in determining individuals' labour market position in Germany, our results correspond closely to those of Breen and Karlson (2014), who find that in Britain educational attainment also accounts for about half of the effect of parental class on individuals' social class position.

${ }^{7}$ It should be noted that our estimates of the proportion of the parental class effect on individuals' social class position that is mediated by educational attainment are lower-bound estimates, since there is likely to be some more subtle variation in individuals' educational attainment (such as the prestige of the school or university attended) which is not captured in our data, but which may affect individuals' social class position.

8 The reason for the difference between our results and those reported by Ishida et al. (1995) is likely due to the fact that we use a decomposition method developed for the use with categorical dependent variables, while Ishida et al. (1995) infer the importance of education in mediating the social origin effect of individuals social destination by comparing coefficients across non-linear models. The latter approach has been argued to be inaccurate as coefficients cannot be directly compared across different nonlinear models due to the scaling effects of the differing unobserved heterogeneity across non-linear models (see, e.g., Mood, 2010; Karlson et al., 2012).

9 We checked that the parallel regression assumption holds by running a series of binary logit models for different educational thresholds. We found that the results hold across these thresholds.

10 The existing literature suggests several potential mechanisms that may account for this 'direct' effect of parental class on children's class destination, including the role of parents' professional networks and wealth in aiding individuals' transition into the labour market (see, e.g., Bernardi and Ballarino, 2016; Pfeffer and Hällsten, 2012), as well as individuals' cognitive and non-cognitive development (see, e.g., Gugushvili et al., 2017).

11 As is the case for the results from our decomposition analysis, running our models separately using the SOEP and the ALLBUS data lead us to the same conclusions with regards to over-time changes in the associations of the OED triangle (see Tables A3 and A4 in the Appendix). 


\section{References}

Andrews D and Leigh A (2009) More inequality, less social mobility. Applied Economics Letters 16(15): 1489-1492.

Atkinson AB (2008) The Changing Distribution of Earnings in OECD Countries. Oxford University Press on Demand.

Bell D (1976) The coming of the post-industrial society. The Educational Forum 40: 574-579.

Bernardi F and Ballarino G (2016) Education, Occupation and Social Origin: A Comparative Analysis of the Transmission. Cheltenham, UK: Edward Elgar Publishing.

Betthäuser BA (2017) Protecting outsiders? Corporatism and the dualisation of unemployment protection in Germany and Austria. European Journal of Social Security, 19(3), pp.209-224.

Betthäuser BA (2018) Fostering equality of opportunity? Compulsory schooling reform and social mobility in Germany. European Sociological Review, 33(5), pp.633-644.

Betthäuser BA (2019) The Effect of the Post-Socialist Transition on Inequality of Educational Opportunity: Evidence from German Unification. European Sociological Review (forthcoming).

BMAS (2001) Lebenslagen in Deutschland: der Armuts- und Reichtumsbericht der Bundesregierung. Bonn: Bundesministerium für Arbeit und Soziales.

Breen R (2010) Educational Expansion and Social Mobility in the 20th Century. Social Forces 89(2): 365-388.

Breen R and Jonsson JO (2005) Inequality of opportunity in comparative perspective: Recent research on educational attainment and social mobility. Annu. Rev. Sociol. 31: 223-243.

Breen R and Jonsson JO (2007) Explaining Change in Social Fluidity: Educational Equalization and Educational Expansion in Twentieth-Century Sweden. American Journal of Sociology 112(6): 1775-1810.

Breen R and Karlson KB (2014) Education and social mobility: New analytical approaches. European Sociological Review 30(1): 107-118.

Breen R and Luijkx R (2007) Social mobility and education: A comparative analysis of period and cohort trends in Britain and Germany. In: Scherer S, Pollak R, Otte G, et al. (eds) From Origin to Destination: Trends in Social Stratification Research. Frankfurt: Campus Verlag, pp. 102-124.

Breen R and Rottman DB (2014) Class Stratification: Comparative Perspectives. Routledge. 
Breen R, Luijkx R, Müller W, et al. (2009) Non-Persistent Inequality in Educational Attainment: Evidence from eight European Countries. American Journal of Sociology 114(5): 1475-1521.

Breen R, Luijkx R, Müller W, et al. (2010) Long-term trends in educational inequality in Europe: Class inequalities and gender differences. European Sociological Review 26(1): 31-48.

Bukodi E and Goldthorpe JH (2011) Class Origins, Education and Occupational Attainment in Britain. European Societies 13(3): 347-375.

Bukodi E and Goldthorpe JH (2013) Decomposing 'social origins': The effects of parents' class, status, and education on the educational attainment of their children. European Sociological Review 29(5): 1024-1039.

Bukodi E, Paskov M and Nolan B (2017) Intergenerational class mobility in Europe: A new account and an old story. INET Oxford Working Paper 17(04).

Bukodi E, Eibl F, Buchholz S, et al. (2018) Linking the macro to the micro: a multidimensional approach to educational inequalities in four European countries. European Societies 20(1): 26-64.

Corak M (2013) Income Inequality, Equality of Opportunity, and Intergenerational Mobility. Journal of Economic Perspectives 27(3): 79-102.

Crompton R (2008) Class and Stratification. Cambridge: Polity.

Eichhorst W and Marx P (2011) Reforming German labour market institutions: A dual path to flexibility. Journal of European Social Policy 21(1): 73-87.

Emmenegger P, Häusermann S, Palier B, et al. (2012) The Age of Dualization: The Changing Face of Inequality in Deindustrializing Societies. Oxford; New York: Oxford University Press.

Erikson R (1984) Social class of men, women and families. Sociology 18(4): 500-514.

Erikson R and Goldthorpe JH (1992) The Constant Flux: A Study of Class Mobility in Industrial Societies. Oxford: Oxford University Press.

Goldthorpe JH (2007) Outline of a theory of social mobility. In: On Sociology: Volume Two. Stanford: Stanford University Press, pp. 154-185.

Goldthorpe JH (2013) Understanding-and misunderstanding-Social mobility in Britain: The entry of the economists, the confusion of politicians and the limits of educational policy. Journal of Social Policy 42(3): 431-450.

Goldthorpe JH and Marshall G (1992) The promising future of class analysis: a response to recent critiques. Sociology 26(3): 381-400. 
Gugushvili A, Bukodi E and Goldthorpe JH (2017) The Direct Effect of Social Origins on Social Mobility Chances: 'Glass Floors' and 'Glass Ceilings' in Britain. European Sociological Review 33(2): 305-316.

Hertel FR (2017) Social Mobility in the 20th Century: Class Mobility and Occupational Change in the United States and Germany.

Hout M (1988) More Universalism, Less Structural Mobility: The American Occupational Structure in the 1980s. American Journal of Sociology 93(6): 1358-1400.

Ishida H, Muller W and Ridge JM (1995) Class origin, class destination, and education: A cross-national study of ten industrial nations. American Journal of Sociology: 145-193.

Jackson M (2013) Determined to Succeed?: Performance versus Choice in Educational Attainment. Stanford University Press.

Jerrim J (2013) Confusion in the (social mobility) ranks? Interpreting international comparisons. In: IOE London Blog.

Kaelble H (2007) Sozialgeschichte Europas: 1945 bis zur Gegenwart. C.H.Beck.

Karlson KB, Holm A and Breen R (2012) Comparing regression coefficients between same-sample nested models using logit and probit: A new method. Sociological Methodology 42(1): 286-313.

Kuha J (2013) Trends in intergenerational class mobility in Britain: New findings from the analysis of birth cohort data.

Leibfried S and Tennstedt F (1985) Armenpolitik und Arbeiterpolitik. Zur Entwicklung und Krise der traditionellen Sozialpolitik der Verteilungsformen. In: Leibfried S and Tennstedt F (eds) Politik der Armut und die Spaltung des Sozialstaats. Frankfurt:

Suhrkamp.

Leibfried S, Leisering L, Buhr P, et al. (1995) Zeit Der Armut. Frankfurt: Suhrkamp.

Lindbeck A and Snower DJ (1988) The Insider-Outsider Theory of Employment and Unemployment. Cambridge: MIT Press.

Marshall G (1997) Repositioning Class: Social Inequality in Industrial Societies. London: Sage. Mayer KU and Aisenbrey S (2007) Variations on a theme: Trends in social mobility in (West) Germany for cohorts born between 1919 and 1971. In: Scherer S, Pollak R, Otte G, et al. (eds) From Origin to Destination: Trends in Social Stratification Research. Frankfurt: Campus Verlag, pp. 125-156.

Mayer KU and Solga H (1994) Mobilität und Legitimität: Zum Vergleich der Chancenstrukturen in der alten DDR und der alten BRD oder: Haben Mobilitätschancen zu Stabilität und Zusammenbruch der DDR beigetragen? Kölner Zeitschrift für Soziologie und Sozialpsychologie 46(2): 193-208. 
Mood C (2010) Logistic regression: Why we cannot do what we think we can do, and what we can do about it. European sociological review 26(1): 67-82.

Müller W and Gangl M (2003) Transitions from Education to Work in Europe: The Integration of Youth into EU Labour Markets. Oxford University Press Oxford.

Müller W and Haun D (1994) Bildungsungleichheit im sozialen Wandel. MZES Arbeitspapier 7.

Müller W and Pollak R (2004) Social mobility in West Germany. In: Breen R (ed.) Social Mobility in Europe. Oxford: Oxford University Press, pp. 77-113.

Müller W and Pollak R (2015) Bildung und soziale Mobilität in Deutschland. AStA Wirtschafts- und Sozialstatistisches Archiv 9(1): 5-26.

Neugebauaer M, Reimer D, Schindler S, et al. (2013) Inequality in Transitions to Secondary and Tertiary Education in Germany. In: Jackson M (ed.) Determined to Succeed?: Performance versus Choice in Edcuational Attainment. Stanford: Stanford University Press, pp. 56-88.

OECD (2011) Divided We Stand: Why Inequality Keeps Rising. Paris: OECD.

Ostheim T and Schmidt MG (2007) Sozialpolitik nach der Wiedervereinigung. In: Schmidt MG, Ostheim T, Siegel N, et al. (eds) Der Woblfahrtsstaat: eine Einfübrung in den bistorischen und internationalen Vergleich. Wiesbaden: Verlag für Sozialwissenschaften.

Palier B and Thelen K (2010) Institutionalizing dualism: Complementarities and change in France and Germany. Politics \& Society 38(1): 119-148.

Pfeffer F and Hällsten M (2012) Mobility regimes and parental wealth: The United States, Germany, and Sweden in comparison. University of Michigan, Population Studies Center, Working Paper 12(76).

Pollak R (2000) Bildung und soziale Mobilität in Deutschland: Institutionelle und bistorische Ursachen für die Entwicklung sozialer Mobilität über fünf Geburtskoborten 1920-1969. Universität Mannheim, Fakultät für Sozialwissenschaften.

Pollak R and Müller W (2004) Soziale Mobilität in Ost- und Westdeutschland im ersten Jahrzehnt nach der Wiedervereinigung. In: Schmitt-Beck RD, Wasmer M, and Koch A (eds) Sozialer Und Politischer W andel in Deutschland. Berlin: Springer-Verlag.

Prandy K and Lambert P (2003) Marriage, social distance and the social space: an alternative derivation and validation of the Cambridge Scale. Sociology 37(3): 397-411.

Rawls J (1971) A Theory of Justice. Harvard university press.

Rose D and Harrison E (eds) (2010) Social Class in Europe: An Introduction to the European Socio-Economic Classification. London: Routledge. 
Schneider S (2006) Applying the ISCED-97 to the German educational qualifications. In: Schneider S (ed.) The International Standard Classification of Education: An Evaluation of Content and Criterion V alidity for 15 European Countries. Mannheim: MZES, pp. 76-102.

Scott J (1996) Stratification and Power: Structures of Class, Status and Command. Cambridge: Polity Press.

Seeleib-Kaiser M, Saunders AM and Naczyk M (2011) Social protection dualism, deindustrialization and cost containment. In: Bradley D (ed.) Comparing European Workers Part B: Policies and Institutions. Emerald Group, pp. 83-118.

Shavit Y and Blossfeld H-P (1993) Persistent Inequality: Changing Educational Attainment in Thirteen Countries. Boulder: Westview Press.

Wagner G, Frick J and Schupp J (2007) The German Socio-Economic Panel Study (GSOEP): Scope, evolution and enhancements. Journal of Applied Social Science Studies (127): 139-169.

Wasmer M, Blohm M, Walter J, et al. (2014) Konzeption und Durchführung der Allgemeinen Bevölkerungsumfrage der Sozialwissenschaften (ALLBUS). GESIS Technical Report 22. Mannheim: GESIS.

White IR, Royston P and Wood AM (2010) Multiple imputation using chained equations: Issues and guidance for practice. Statistics in Medicine 30(4): 377-399.

Wirth H, Gresch C, Müller W, et al. (2010) Measuring social class: The case of Germany. In: Rose D and Harrison E (eds) Social Class in Europe: An Introduction to the European Socio-Economic Classification. London: Routledge, pp. 114-137.

Wren A (2013) The Political Economy of the Service Transition. Oxford: Oxford University Press.

Wright EO (2008) Logics of class analysis. In: Lareau A and Conley D (eds) Social Class: How Does It Work? New York: Russell Sage Foundation, pp. 329-349. 
Figures

Figure 1. Predicted probability of attaining a position above the first and second labour market cut-off, by birth cohort, binomial logit

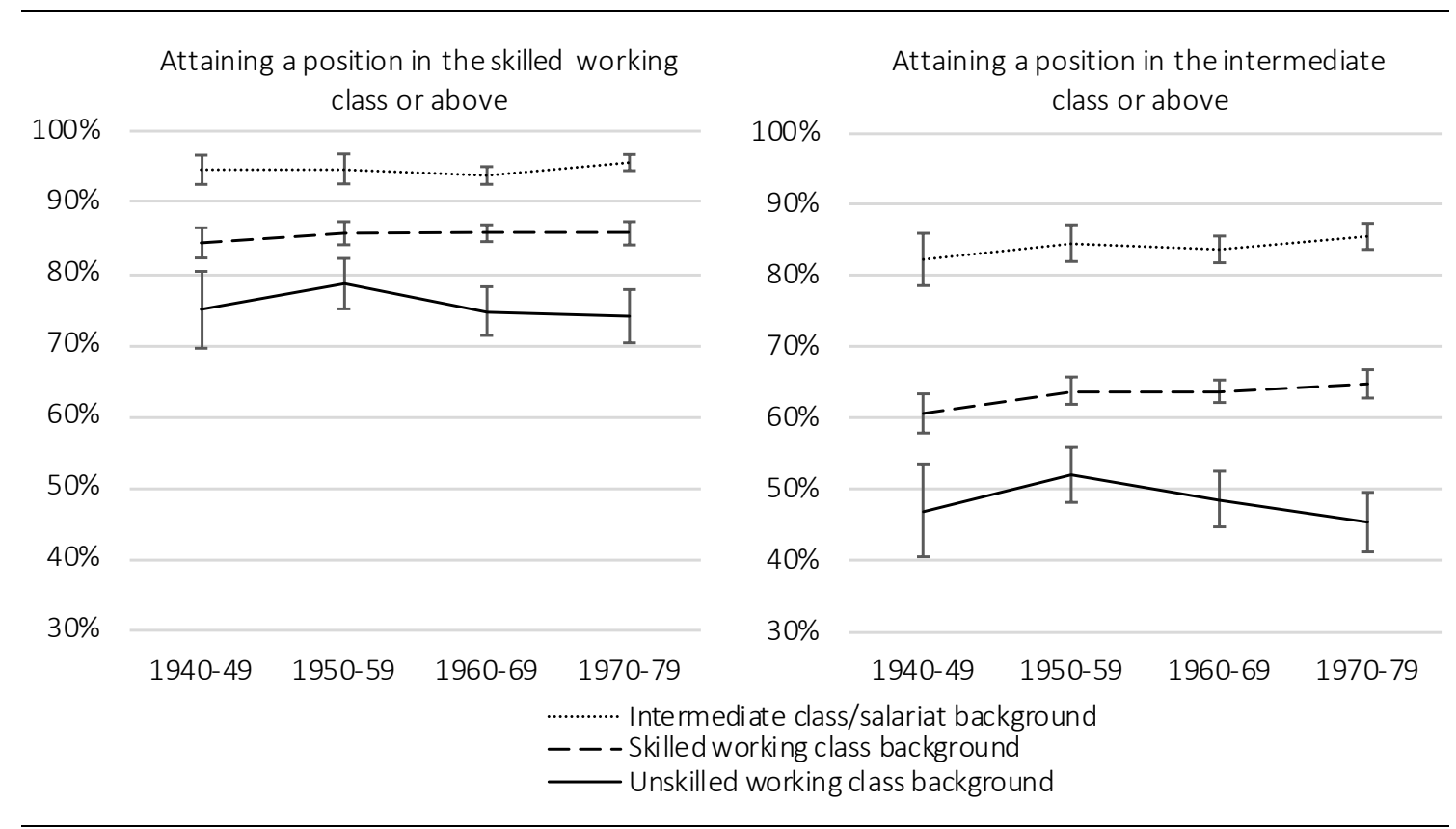

Notes: 95\% Confidence Intervals; Predicted probabilities based on M2 and M4 in Table A1 (SOEP) 


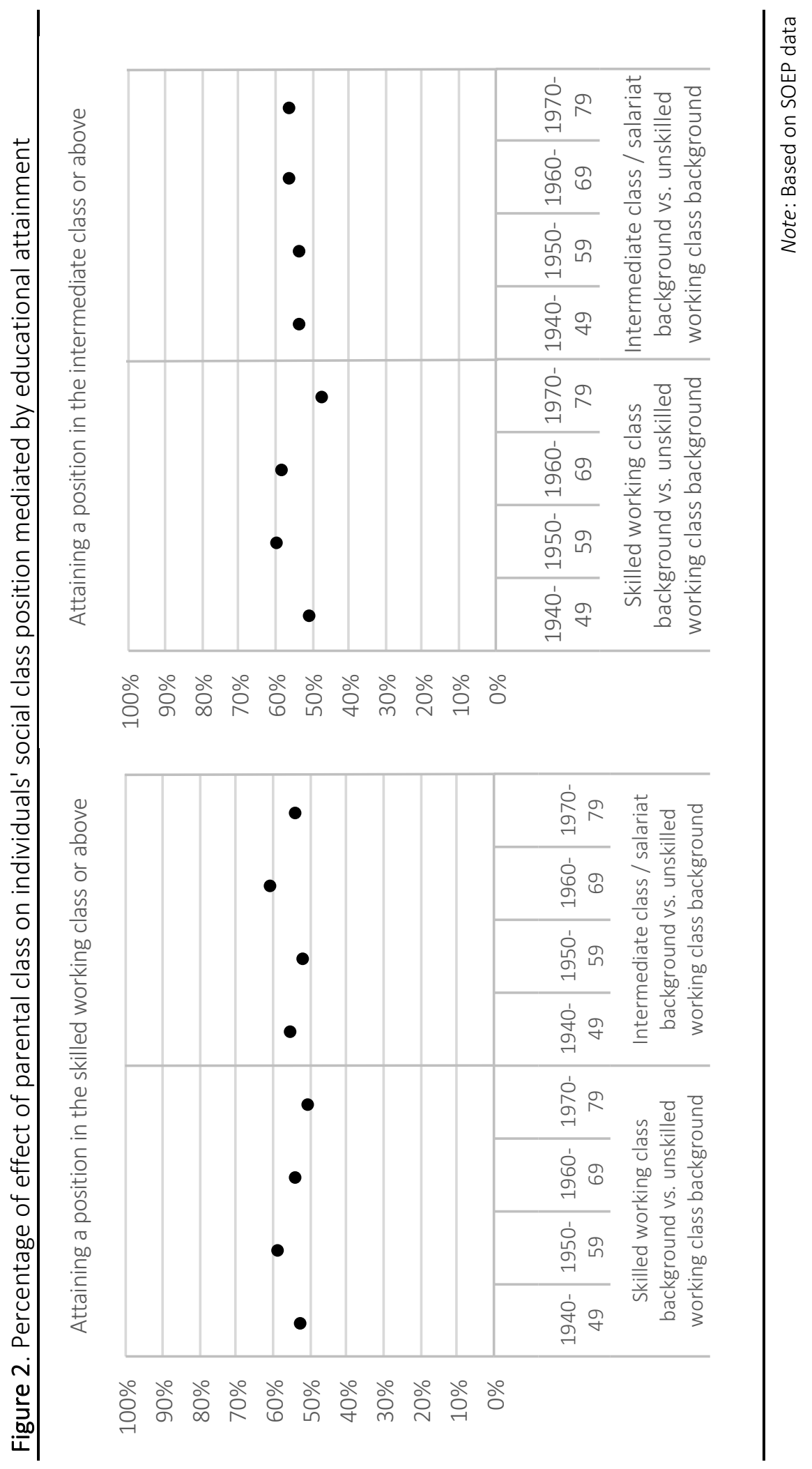


Figure A1. Predicted probability of attaining a position above the first and second labour market cut-off, binomial logit (ALLBUS)

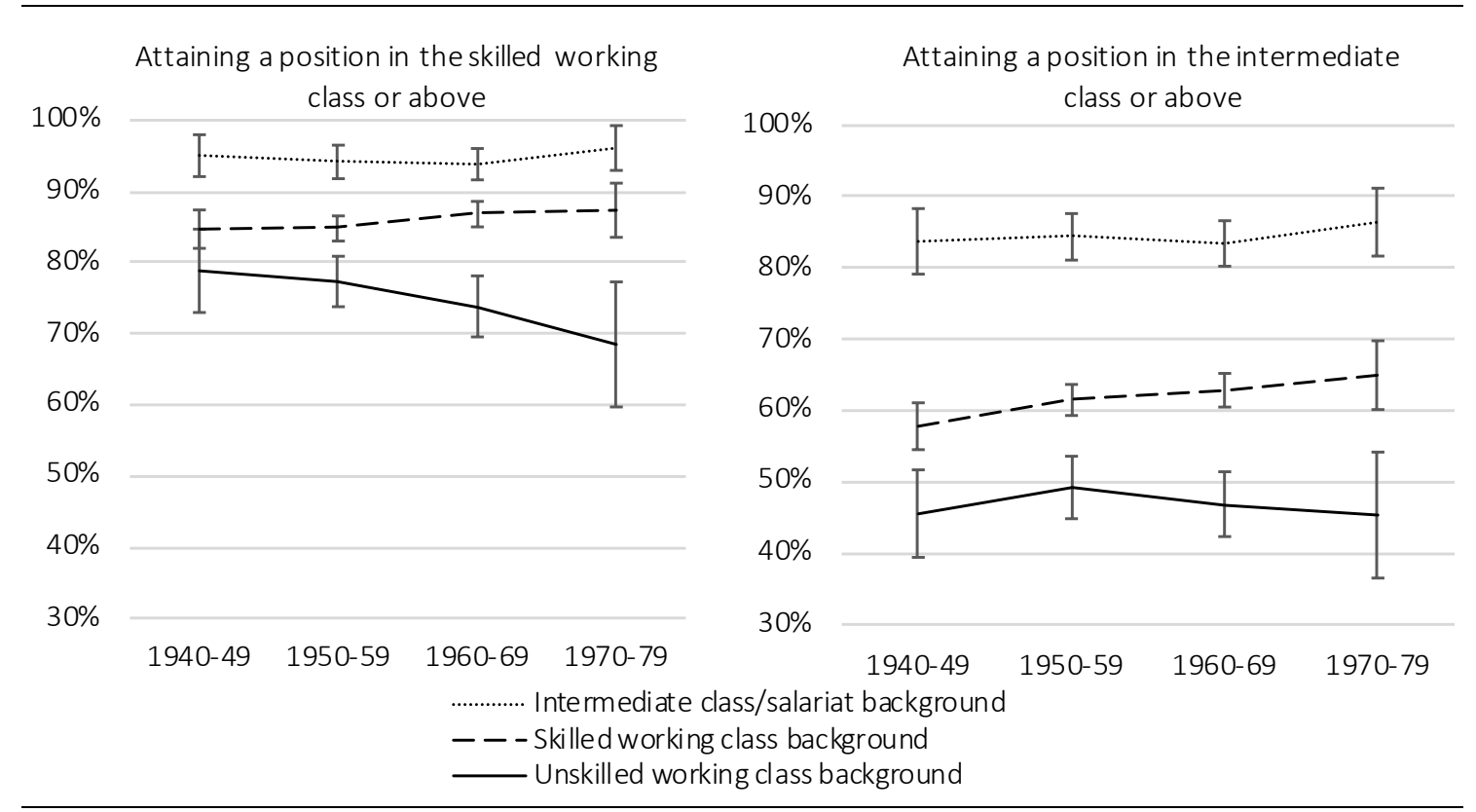

Notes: 95\% Confidence Intervals; Predicted probabilities based on M2 and M4 in Table A2 (ALLBUS) 


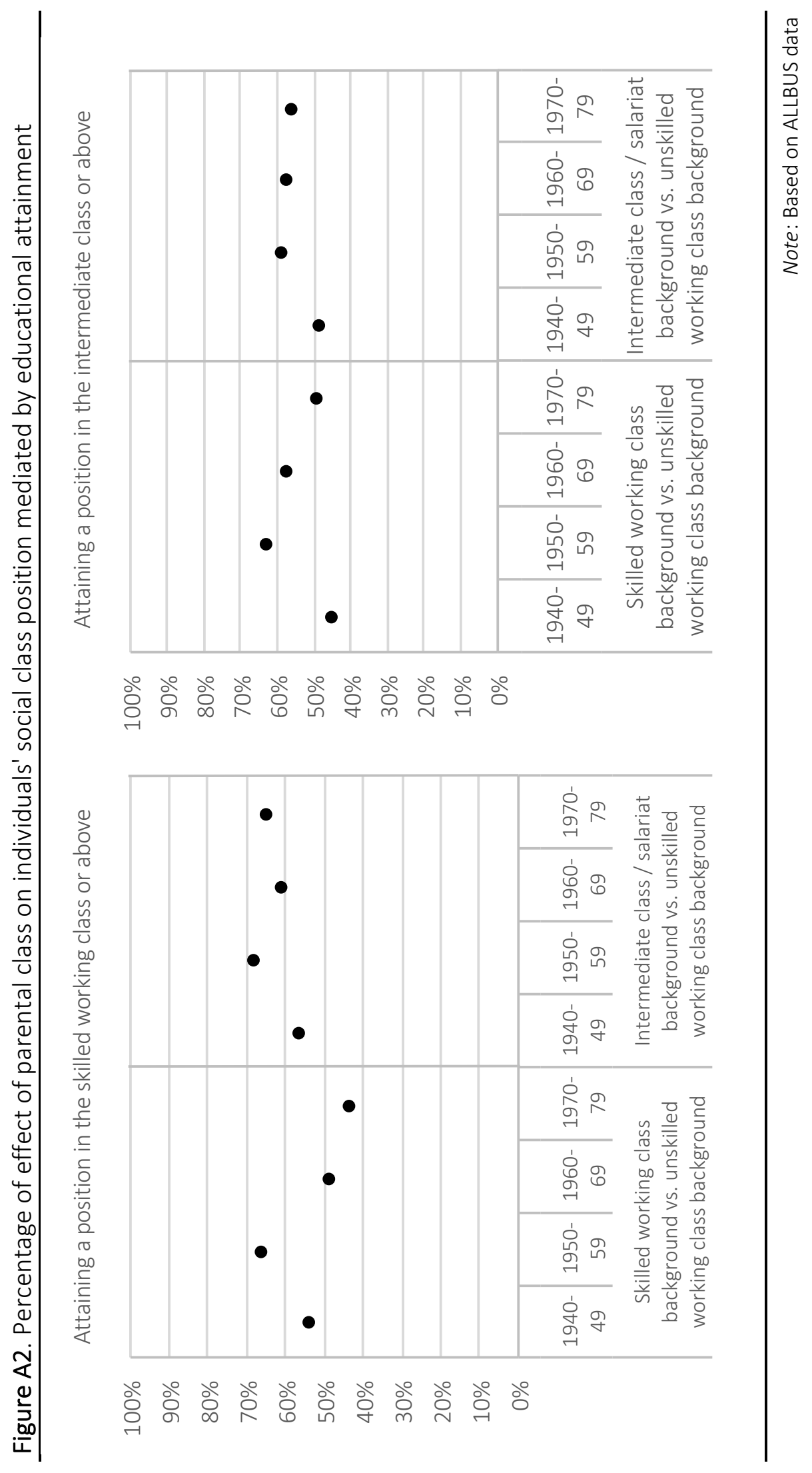


Tables

Table 1. Expected effects of key macro-level trends on the relative labour market chances of individuals from unskilled working-class backgrounds, by birth cohort

\begin{tabular}{lc|c|c|c}
\hline & \multicolumn{4}{c}{ Birth cohort } \\
\cline { 2 - 5 } & $1940-49$ & $1950-59$ & $1960-69$ & $1970-79$ \\
\hline Educational equalization and expansion & 0 & 0 & 0 & 0 \\
\hline Post-war depression & - & & & \\
\hline Wirtschaftswunder / welfare state expansion & ++ & + & -- \\
\hline Oil-crisis / welfare state retrenchment & & & - \\
\hline \multicolumn{3}{c}{ Notes: +/- indicate the expected effects of the respective macro-level trend on the relative } \\
labour market chances of individuals from unskilled working-class backgrounds. \\
'o' indicates that no clear expectation could be derived.
\end{tabular}

Table 2. Distribution of key variables across birth cohorts (\%)

\begin{tabular}{lcccc}
\hline & \multicolumn{4}{c}{ Birth Cohort } \\
\cline { 2 - 5 } & $1940-49$ & $1950-59$ & $1960-69$ & $1970-79$ \\
\hline \hline Social class position of parents & & & & \\
1. Unskilled working class & 14.6 & 16.0 & 14.4 & 13.9 \\
2. Skilled working class & 61.2 & 59.9 & 57.3 & 53.8 \\
3. Salariat \& Intermediate & 24.2 & 24.1 & 28.4 & 32.3 \\
Social class position of cohort members & & & & \\
1. Unskilled working class & 14.4 & 13.2 & 13.5 & 12.5 \\
2. Skilled working class & 45.7 & 45.8 & 45.9 & 45.0 \\
3. Salariat \& Intermediate & 39.9 & 41.0 & 40.6 & 42.4 \\
Educational attainment & & & & \\
1. Mid-secondary or less & 12.2 & 10.2 & 8.7 & 8.0 \\
2. Upper-secondary & 51.8 & 49.7 & 47.5 & 45.2 \\
3. Post-secondary & 1.5 & 3.7 & 7.9 & 10.4 \\
4. Tertiary & 34.5 & 36.4 & 35.9 & 36.4 \\
\hline
\end{tabular}


Table 3. Over-time change in the effect of parental class on educational attainment, ordered logit, odds ratios

\begin{tabular}{|c|c|c|}
\hline & M1 & M2 \\
\hline \multicolumn{3}{|l|}{ Parental class } \\
\hline \multicolumn{3}{|l|}{ 1. Unskilled working class (rf.) } \\
\hline 2. Skilled working class & $2.101 * * *$ & $1.949 * * *$ \\
\hline 3. Salariat \& Intermediate & $7.296 * * *$ & $7.200 * * *$ \\
\hline \multicolumn{3}{|l|}{ Birth cohort } \\
\hline $1940-49$ & $0.765 * * *$ & $0.761 *$ \\
\hline \multicolumn{3}{|l|}{$1950-59(r f)}$. \\
\hline $1960-69$ & $1.110 * *$ & 1.011 \\
\hline 1970-79 & $1.241 * * *$ & 1.160 \\
\hline \multicolumn{3}{|l|}{ Birth cohort * Parental class } \\
\hline 1940-49* Skilled working class & & 1.006 \\
\hline 1940-49 * Salariat \& Intermediate & & 1.009 \\
\hline $1960-69 *$ Skilled working class & & 1.167 \\
\hline 1960-69 * Salariat \& Intermediate & & 1.006 \\
\hline 1970-79* Skilled working class & & 1.087 \\
\hline 1970-79 * Salariat \& Intermediate & & 1.059 \\
\hline
\end{tabular}


Table 4. Over-time change in the effect of parental class and individuals' educational attainment on their social class position at age 34 , binary logit, odds ratios

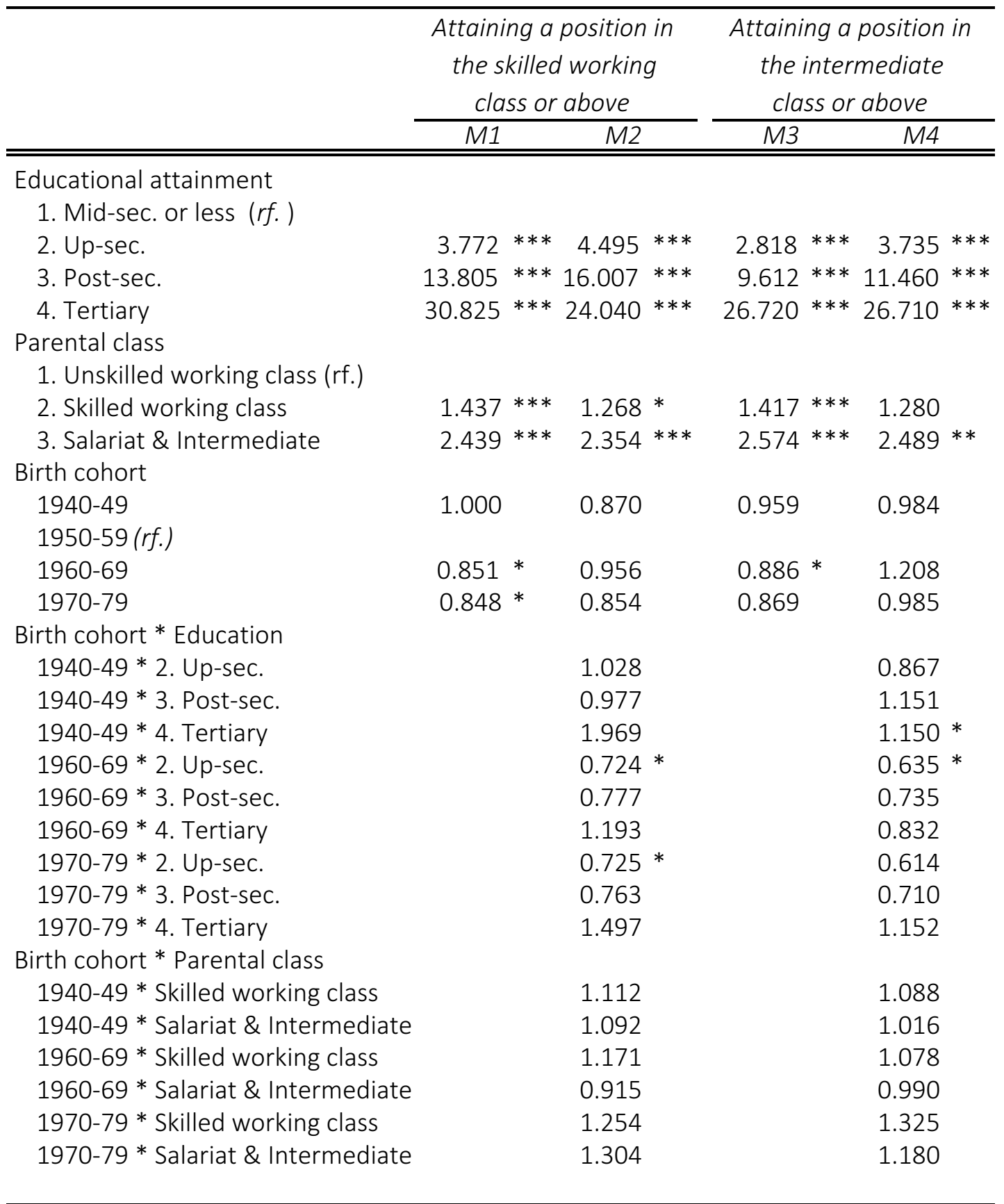

$* \mathrm{p}<0.05, * * \mathrm{p}<0.01, * * * \mathrm{p}<0.001, \mathrm{~N}: 19,578$ (SOEP) Notes: Gender and age controlled for in all models (not shown) 
Table A1. Over-time change in the effect of parental class on labour market position at age 34, binary logit, odds ratios

\begin{tabular}{|c|c|c|c|c|}
\hline & \multicolumn{2}{|c|}{ 1st Labour Market } & \multicolumn{2}{|c|}{ 2nd Labour Market } \\
\hline & M1 & $\mathrm{M} 2$ & M3 & M4 \\
\hline \multicolumn{5}{|l|}{ Parental class } \\
\hline \multicolumn{5}{|l|}{ 1. Unskilled working class (rf.) } \\
\hline 2. Skilled working class & $1.893 * * *$ & $1.628 * * *$ & $1.847 * * *$ & $1.629 * * *$ \\
\hline 3. Salariat \& Intermediate & $5.622 * * *$ & $4.873 * * *$ & $5.656 * * *$ & $5.070 * * *$ \\
\hline \multicolumn{5}{|l|}{ Birth cohort } \\
\hline 1940-49 & 0.887 & 0.816 & $0.857^{* *}$ & 0.819 \\
\hline \multicolumn{5}{|l|}{$1950-59(r f)}$. \\
\hline 1960-69 & 0.922 & 0.802 & 0.960 & 0.873 \\
\hline 1970-79 & 0.967 & 0.778 & 0.994 & $0.766 *$ \\
\hline \multicolumn{5}{|l|}{ Birth cohort * Parental class } \\
\hline 1940-49* Skilled working class & & 1.106 & & 1.065 \\
\hline 1940-49 * Salariat \& Intermediate & & 1.204 & & 1.034 \\
\hline 1960-69 * Skilled working class & & 1.240 & & 1.141 \\
\hline 1960-69 * Salariat \& Intermediate & & 1.044 & & 1.072 \\
\hline 1970-79* Skilled working class & & 1.287 & & $1.360 *$ \\
\hline 1970-79 * Salariat \& Intermediate & & 1.560 & & 1.405 \\
\hline
\end{tabular}


Table A2. Over-time change in the effect of parental class on labour market position at age 34, binary logit, odds ratios

\begin{tabular}{|c|c|c|c|c|}
\hline & \multicolumn{2}{|c|}{$\begin{array}{c}\text { 1st Labour Market } \\
\text { Threshold }\end{array}$} & \multicolumn{2}{|c|}{$\begin{array}{c}\text { 2nd Labour Market } \\
\text { Threshold }\end{array}$} \\
\hline & M1 & M2 & M3 & M4 \\
\hline \multicolumn{5}{|l|}{ Parental class } \\
\hline \multicolumn{5}{|l|}{ 1. Unskilled working class (rf.) } \\
\hline 2. Skilled working class & $1.923 * * *$ & $1.642 * * *$ & $1.779 * * *$ & $1.648 * * *$ \\
\hline 3. Salariat \& Intermediate & $5.449 * * *$ & $4.775 * * *$ & $5.894 * * *$ & $5.583 * * *$ \\
\hline \multicolumn{5}{|l|}{ Birth cohort } \\
\hline 1940-49 & 1.069 & 1.145 & $0.867 *$ & 0.863 \\
\hline \multicolumn{5}{|l|}{ 1950-59 (rf.) } \\
\hline $1960-69$ & 1.032 & 0.819 & 1.010 & 0.910 \\
\hline 1970-79 & 1.106 & 0.693 & 1.090 & 0.856 \\
\hline \multicolumn{5}{|l|}{ Birth cohort * Parental class } \\
\hline 1940-49* Skilled working class & & 0.906 & & 0.994 \\
\hline 1940-49 * Salariat \& Intermediate & & 1.085 & & 1.106 \\
\hline $1960-69 *$ Skilled working class & & 1.426 & & 1.164 \\
\hline 1960-69 * Salariat \& Intermediate & & 1.132 & & 1.025 \\
\hline 1970-79* Skilled working class & & $1.941 *$ & & 1.357 \\
\hline 1970-79 * Salariat \& Intermediate & & 2.397 & & 1.379 \\
\hline
\end{tabular}


Table A3. Over-time change in the effect of parental background on educational attainment, ordered logit, odds ratios

\begin{tabular}{|c|c|c|}
\hline & $M 1$ & M2 \\
\hline \multicolumn{3}{|l|}{ Parental class } \\
\hline \multicolumn{3}{|l|}{ 1. Unskilled working class (rf.) } \\
\hline 2. Skilled working class & $2.023 * * *$ & $1.979 * * *$ \\
\hline 3. Salariat \& Intermediate & $7.800 * * *$ & $7.930 * * *$ \\
\hline \multicolumn{3}{|l|}{ Birth cohort } \\
\hline 1940-49 & $0.649 * * *$ & $0.721 *$ \\
\hline \multicolumn{3}{|l|}{$1950-59(r f)}$. \\
\hline $1960-69$ & $1.205 * * *$ & 1.135 \\
\hline 1970-79 & $1.336 * * *$ & 1.178 \\
\hline \multicolumn{3}{|l|}{ Birth cohort * Parental class } \\
\hline 1940-49* Skilled working class & & 0.852 \\
\hline 1940-49* Salariat \& Intermediate & & 0.984 \\
\hline $1960-69 *$ Skilled working class & & 1.123 \\
\hline 1960-69* Salariat \& Intermediate & & 0.940 \\
\hline $1970-79 *$ Skilled working class & & 1.164 \\
\hline 1970-79* Salariat \& Intermediate & & 1.160 \\
\hline
\end{tabular}


Table A4. Over-time change in the effect of educational attainment on labour market position at age 34 , binary logit, odds ratios (ALLBUS)

\begin{tabular}{|c|c|c|c|c|}
\hline & \multicolumn{2}{|c|}{$\begin{array}{c}\text { Attaining a position in } \\
\text { the skilled working } \\
\text { class or above }\end{array}$} & \multicolumn{2}{|c|}{$\begin{array}{c}\text { Attaining a position in } \\
\text { the intermediate } \\
\text { class or above }\end{array}$} \\
\hline & $M 1$ & $M 2$ & M3 & M4 \\
\hline \multicolumn{5}{|l|}{$\begin{array}{l}\text { Educational attainment } \\
\text { 1. Mid-sec. or less (rf.) }\end{array}$} \\
\hline 2. Up-sec. & $5.924 * * *$ & $5.792 * * *$ & $3.604^{* * *}$ & $3.530 * * *$ \\
\hline 3. Post-sec. & $25.322 * * *$ & $29.489 * * *$ & $15.199 * * *$ & $16.929 * * *$ \\
\hline 4. Tertiary & $57.310 * * *$ & $60.685 * * *$ & $34.243 * * *$ & $33.507 * * *$ \\
\hline \multicolumn{5}{|l|}{ Parental class } \\
\hline \multicolumn{5}{|l|}{ 1. Unskilled working class (rf.) } \\
\hline 2. Skilled working class & $1.469 * * *$ & 1.248 & $1.371 * * *$ & $1.268 *$ \\
\hline 3. Salariat \& Intermediate & $2.100 * * *$ & $1.834 *$ & $2.574 * * *$ & $2.416 * * *$ \\
\hline \multicolumn{5}{|l|}{ Birth cohort } \\
\hline $\begin{array}{l}1940-49 \\
1950-59(r f .)\end{array}$ & $1.399 * *$ & 1.354 & 1.066 & 1.145 \\
\hline $1960-69$ & 0.938 & 0.778 & 0.891 & 0.698 \\
\hline 1970-79 & 0.969 & 0.543 & 0.914 & 0.545 \\
\hline \multicolumn{5}{|l|}{ Birth cohort * Educational attainmer } \\
\hline 1940-49* 2. Up-sec. & & 1.057 & & 0.865 \\
\hline 1940-49*3. Post-sec. & & 0.476 & & 0.558 \\
\hline 1940-49* 4. Tertiary & & 0.745 & & 0.766 \\
\hline 1960-69* 2. Up-sec. & & 0.993 & & 1.193 \\
\hline 1960-69*3. Post-sec. & & 0.994 & & 1.072 \\
\hline $1960-69 * 4$. Tertiary & & 0.755 & & 1.241 \\
\hline 1970-79* 2. Up-sec. & & 1.123 & & 1.405 \\
\hline 1970-79*3. Post-sec. & & 0.629 & & 1.074 \\
\hline 1970-79* 4. Tertiary & & 1.000 & & 1.471 \\
\hline \multicolumn{5}{|l|}{ Birth cohort * Parental class } \\
\hline 1940-49* Skilled working class & & 1.017 & & 1.086 \\
\hline 1940-49 * Salariat \& Intermediate & & 1.190 & & 1.209 \\
\hline $1960-69 *$ Skilled working class & & 1.368 & & 1.117 \\
\hline 1960-69 * Salariat \& Intermediate & & 1.170 & & 1.029 \\
\hline $1970-79 *$ Skilled working class & & $1.958 *$ & & 1.327 \\
\hline 1970-79 * Salariat \& Intermediate & & 1.718 & & 1.231 \\
\hline
\end{tabular}

${ }^{*} p<0.05,{ }^{* *} p<0.01,{ }^{* * *} p<0.001, \mathrm{~N}: 8,798$ (ALLBUS)

Notes: Gender and age controlled for in all models (not shown) 
Table A5. Composition of social origin groups by parental status score and parental education score (\%)

\begin{tabular}{lcccc}
\hline & \multicolumn{4}{c}{ Birth Cohort } \\
\cline { 2 - 5 } & $1940-49$ & $1950-59$ & $1960-69$ & $1970-79$ \\
\hline \hline & \multicolumn{4}{c}{ Unskilled working class background } \\
Parental status score & 30.04 & 30.34 & 31.87 & 32.48 \\
Parental education score & 24.57 & 24.20 & 29.58 & 32.17 \\
\hline & \multicolumn{4}{c}{ Skilled working clss background } \\
Parental status score & 38.43 & 38.59 & 39.48 & 40.05 \\
Parental education score & 33.38 & 34.81 & 38.96 & 41.68 \\
\hline & Intermediate class and salariat background \\
Parental status score & 56.06 & 55.68 & 57.16 & 59.01 \\
Parental education score & 47.46 & 50.28 & 55.53 & 60.60 \\
\hline
\end{tabular}

Notes: Parental status score is based on the normalised CAMSIS scale of social status (see Prandy and Lambert, 2003). The parental education score is based on a normalised composite measure of fathers' and mother' education, following the approach outlines in Bukodi and Goldthorpe (2013).

$\mathrm{N}: 19,578$ (SOEP) 
Table A6. Overall social fluidity measured using log-linear models on the table of Cohort (C)Class of Origin (O)-Class of Destination (D)

\begin{tabular}{|c|c|c|c|c|}
\hline & $\mathrm{G}^{2}$ & d.f. & $\mathrm{p}$ & $\mathrm{DI}(\%)$ \\
\hline (1) $C O C D O D$ & 69.98 & 108.00 & 1.00 & 2.10 \\
\hline (2) $\mathrm{CO} C D \beta_{C} \mathrm{OD}$ & 62.68 & 105.00 & 1.00 & 2.00 \\
\hline (2) - (1) & 7.30 & 3.00 & 0.06 & \\
\hline \multicolumn{5}{|c|}{$B_{C}$ parameters under UNIDIFF } \\
\hline 1940s cohort (C1) & 0.97 & & & \\
\hline 1950s cohort (C2) & 1.00 & & & \\
\hline 1960s cohort (C3) & 1.01 & & & \\
\hline 1970s cohort (C4) & 1.13 & & & \\
\hline \multicolumn{5}{|l|}{ Only $\mathrm{C} 1$ and $\mathrm{C} 2$} \\
\hline (1) $C O C D O D$ & 14.53 & 36.00 & 1.00 & 1.50 \\
\hline (2) $\mathrm{CO} C D \beta_{C} \mathrm{OD}$ & 14.41 & 35.00 & 1.00 & 1.50 \\
\hline$(2)-(1)$ & 0.12 & 1.00 & 0.73 & \\
\hline \multicolumn{5}{|c|}{$b_{C}$ parameters under UNIDIFF } \\
\hline 1940s cohort (C1) & 0.98 & & & \\
\hline 1950s cohort (C2) & 1.00 & & & \\
\hline \multicolumn{5}{|l|}{ Only C2 and C3 } \\
\hline (1) $C O C D O D$ & 18.51 & 36.00 & 0.99 & 1.40 \\
\hline (2) $\mathrm{CO} C D \beta_{C} \mathrm{OD}$ & 18.38 & 35.00 & 0.99 & 1.40 \\
\hline$(2)-(1)$ & 0.12 & 1.00 & 0.73 & \\
\hline \multicolumn{5}{|c|}{$b_{C}$ parameters under UNIDIFF } \\
\hline 1950s cohort (C2) & 1.00 & & & \\
\hline 1960s cohort (C3) & 1.02 & & & \\
\hline \multicolumn{5}{|l|}{ Only C3 and C4 } \\
\hline (1) $C O C D O D$ & 27.83 & 36.00 & 0.83 & 1.60 \\
\hline (2) $\mathrm{CO} C D \beta_{C} \mathrm{OD}$ & 23.12 & 35.00 & 0.94 & 1.50 \\
\hline$(2)-(1)$ & 4.71 & 1.00 & 0.03 & \\
\hline \multicolumn{5}{|c|}{$B_{C}$ parameters under UNIDIFF } \\
\hline 1960s cohort (C3) & 1.00 & & & \\
\hline 1970s cohort (C4) & 1.12 & & & \\
\hline
\end{tabular}


Table A7. Social fluidity between the unskilled working class and higher social classes measured using log-linear models on the table of Cohort (C)-Class of Origin (O)-Class of Destination (D)

\begin{tabular}{|c|c|c|c|c|}
\hline & $\mathrm{G}^{2}$ & d.f. & $p$ & $\mathrm{DI}(\%)$ \\
\hline (1) CO CD OD & 14.15 & 18.00 & 0.72 & 0.70 \\
\hline (2) $\mathrm{CO} C D \beta_{C} O D$ & 10.48 & 15.00 & 0.79 & 0.60 \\
\hline$(2)-(1)$ & 3.67 & 3.00 & 0.30 & \\
\hline \multicolumn{5}{|c|}{$B_{C}$ parameters under UNIDIFF } \\
\hline 1940s cohort & 1.14 & & & \\
\hline 1950s cohort & 1.00 & & & \\
\hline 1960s cohort & 1.01 & & & \\
\hline 1970s cohort & 1.19 & & & \\
\hline \multicolumn{5}{|l|}{ Only $\mathrm{C} 1$ and $\mathrm{C} 2$} \\
\hline (1) CO CD OD & 1.71 & 6.00 & 0.94 & 0.40 \\
\hline (2) $\mathrm{CO} C D \beta_{C} \mathrm{OD}$ & 0.71 & 5.00 & 0.98 & 0.20 \\
\hline (2) - (1) & 0.98 & 1.00 & 0.32 & \\
\hline \multicolumn{5}{|c|}{$B_{C}$ parameters under UNIDIFF } \\
\hline 1940s cohort (C1) & 1.14 & & & \\
\hline 1950s cohort (C2) & 1.00 & & & \\
\hline \multicolumn{5}{|l|}{ Only C2 and C3 } \\
\hline (1) CO CD OD & 5.54 & 6.00 & 0.48 & 0.60 \\
\hline (2) $\mathrm{CO} C D \beta_{C} \mathrm{OD}$ & 5.51 & 5.00 & 0.36 & 0.60 \\
\hline (2) - (1) & 0.03 & 1.00 & 0.82 & \\
\hline \multicolumn{5}{|c|}{$B_{C}$ parameters under UNIDIFF } \\
\hline 1950s cohort (C2) & 1.00 & & & \\
\hline 1960s cohort (C3) & 1.02 & & & \\
\hline \multicolumn{5}{|l|}{ Only C3 and C4 } \\
\hline (1) CO CD OD & 7.00 & 6.00 & 0.32 & 0.50 \\
\hline (2) $\mathrm{CO} C D \beta_{C} \mathrm{OD}$ & 3.10 & 5.00 & 0.68 & 0.30 \\
\hline (2) - (1) & 3.90 & 1.00 & 0.05 & \\
\hline \multicolumn{5}{|c|}{$B_{C}$ parameters under UNIDIFF } \\
\hline 1960s cohort (C3) & 1.00 & & & \\
\hline 1970s cohort (C4) & 1.17 & & & \\
\hline
\end{tabular}

